\title{
Psychosocial consequences of road accidents
}

\author{
UF Malt, B Hфivik, G Blikra \\ Department of Behavioural and Psychosomatic Medicine, The National Hospital, N-0027, Oslo, Norway
}

(Received 23 March 1993; accepted 4 May 1993)

Road traffic accidents constitute about $1 / 3$ of the accidents brought to hospitals and are associated with the most severe injuries. However, the longterm psychosocial consequences have been minimally explored. We present data from a 3-year retrospective follow-up study not previously published in English, concerning the psychosocial outcome of 51 out of 55 injured children, and the consequences of road traffic accidents for 55 relatives of 112 adults suffering from some negative consequences (Malt et al, 1982). We have also performed an analysis of a subsample of 192 road traffic injured subjects included in a previously reported retrospective 3-year follow-up study of a cohort of 551 accidentally injured adults (Malt et al, 1989a).

The method included data from medical records, ratings of severity of the injury, questionnaires including the Late Effect of Accidental Injury Questionnaire (LEAIQ) (Malt et al, 1989b), the General Health Questionnaire 20-item version and personal structured interviews with 112 adults with some negative consequences and 55 of their relatives available at the time of the interview.

Results showed that of the 51 children, $7.8 \%$ had behavioural problems, $4.1 \%$ had impaired playing ability and $14.3 \%$ had reduced physical performance capacity. Sixty-eight of 183 adults had a GHQ-20 case score of 4 or more suggesting psychiatric problems in $31 \%$ of the patients (sensitivity $73 \%$, specificity $79 \%$ ). However, forty-eight adults $(26 \%)$ reported nervousness as a consequence of the road traffic accident. Of these subjects, the majority (33/48 or $87 \%$ ) scored as a case on the GHQ-20. Depressive symptoms were more fre- quently reported than anxiety symptoms. Symptoms suggesting a post-traumatic stress disorder occurred in less than $5 \%$ of the subjects. $29.5 \%$ reported fear of situations similar to that in which the accident took place.

Nervousness was statistically associated with higher age $(P<0.01)$ and severity of the injury $(P$ $=0.016)$. Fourteen $(25.5 \%)$ of the 55 relatives of the 112 patients with some negative physical outcomes, reported worse psychological health, five $(9.1 \%)$ decreased pleasure in leisure and four $(7.3 \%)$ reduced work capacity as a result of their relatives' injury. The family and social consequences of the accidents can be observed in table I.

Table I. Frequency of negative consequences reported in a 3year biopsychosocial follow-up study of persons 15-69 years of age injured in traffic accidents.

\begin{tabular}{lc}
\hline Outcome & $\begin{array}{c}\%(n) \text { of patients } \\
\text { with negative outcome }\end{array}$ \\
\hline $\begin{array}{l}\text { Family/spouse } \\
\text { relationship worse }\end{array}$ & $7.4(14 / 183)$ \\
$\begin{array}{l}\text { Reduced contact } \\
\text { Pleasure in leisure } \\
\text { decreased }\end{array}$ & $15.1(28 / 185)$ \\
$\begin{array}{l}\text { Decreased work } \\
\text { capacity }\end{array}$ & $21.6(40 / 185)$ \\
Economic situation worse & $21.3(40 / 187)$ \\
\hline
\end{tabular}


All outcomes were statistically associated with pre-accident disability problems and severity of the injury. Worse relationship to family and reduced social contact was associated with higher age $(P<0.001)$. We found no association between type of road accidents and negative psychosocial outcomes.

As far as we know, this is the first study to report the long-term consequences of road traffic injuries for both the patients and their relatives. The $20 \%$ activity decrease, the frequent reports of long-term depressive and anxiety symptoms and the psychosocial implications for the relatives of the victims, indicate that the psychiatric and psychosocial consequences of traffic injuries are a major cause of reduced mental health in our society. This finding stresses that not only surgeons, but also psychiatrists should be involved in the after- care of traffic accident victims and their relatives (Malt, 1993).

\section{References}

Malt UF, Blikra G, Hфivik B (1982) Bedre fơre vár. En studie i trafikkskader og deres f $\varnothing$ lger. Nordbyhagen: Kirurgisk avdeling, Sentralsykehuset i Akershus

Malt UF, Blikra G, Hфivik B (1989a) The three-year biopsychosocial outcome of 551 hospitalized accidentally injured adults. Acta Psychiatr Scand 80 (suppl 355), 84-93

Malt UF, Blikra G, Høivik B (1989b) The Late Effect of Accidental Injury Questionnaire (LEAIQ). Acta Psychiatr Scand 80 (suppl 355), 113-130

Malt UF (1993) Traumatic effects of accidents. Ursano. In: Individual and Community Responses to Trauma and Disaster (Ursans RJ, Mc Caughey BG, Fullerton CS, eds). University Press, Cambridge, 103-135 